\title{
Aquatic Therapy Following Total Knee Replacement
}

\section{E. Endang Sri Mariani ${ }^{1,2}$}

1 Department of Physical Medicine and Rehabilitation - Faculty of Medicine - Diponegoro University - Semarang, Indonesia

2 Department of Physical Medicine and Rehabilitation - St. Elisabeth Hospital - Semarang, Indonesia

\begin{abstract}
Total knee replacement (TKR) has revolutionized the care of patients with end-stage knee joint disease. Rehabilitation of TKR commonly consists of land-based exercises as a primary mode, but it may not always be an optimal approach.

Water provides a unique environment. The level of exertion is a function of water properties and the physical laws of motion. Aquatic therapy allows fine gradations of exercise, increase control over the percentage of weight bearing, increase ROM and strength, decrease pain and swelling, and increase confidence in functional movements.

Although there is inconsistency in research results, of all studies aquatic therapy is not said to be worst than land-based therapy. Moreover, it has a positive influence on social behavior and mood. This may be more advantageous in the early postoperative phase when patients are limited by pain.

As a tool, aquatic therapy has desirable and undesirable effects. So, it is important to screen the patients before undergoing aquatic therapy and to assess patient's condition during and after it. However, so far there has been no agreement in post TKR aquatic protocols. The obstacle also may occur on the cost for facility maintenance and hygiene, as well as the availability of competent human resources.
\end{abstract}

Keywords: aquatic therapy, total knee replacemnt 


\begin{abstract}
Penggantian sendi lutut total atau Total Knee Replacement (TKR) telah merevolusi penanganan pasien dengan penyakit sendi lutut tahap akhir. Rehabilitasi TKR umumnya meliputi latihan; latihan di darat sebagai moda utama, tetapi tidak selalu mencapai hasil yang optimal.

Air merupakan lingkungan yang unik. Tingkat pengerahan tenaga merupakan fungsi dari sifat-sifat air dan hukum fisika tentang gerak. Terapi akuatik memungkinkan gradasi yang baik untuk latihan, meningkatkan persentase beban berat badan (weight bearing), meningkatkan lingkup gerak sendi dan kekuatan, menurunkan nyeri dan pembengkakan, serta meningkatkan kepercayaan diri dalam gerakangerakan fungsional.

Walaupun penelitian-penelitian tidak menghasilkan kesimpulan yang sama, dari semua penelitian tersebut tidak ada yang mengatakan bahwa terapi akuatik lebih buruk daripada terapi di darat. Lebih lagi, ada pengaruh positif dalam perilaku sosial dan suasana hati. Hal ini dapat memberikan manfaat dalam fase awal setelah operasi, ketika nyeri masih menjadi kendala bagi pasien.

Sebagai modalitas, terapi akuatik mempunyai efek yang diinginkan dan tidak diinginkan. Sehingga perlu untuk melakukan penapisan sebelum memberikan terapi akuatik dan melakukan penilaian kondisi pasien selama dan sesudahnya. Meskipun demikian, sejauh ini belum ada penetapan protocol akuatik bagi pasien post TKR. Kendala juga dapat timbul dari pertimbangan biaya pemeliharaan fasilitas dan kebersihannya, serta ketersediaan sumber daya manusia yang kompeten.
\end{abstract}

Keywords: terapi akuatik, penggantian sendi lutut total

\section{Correspondent Detail:}

\section{E. Endang Sri Mariani}

E-mail : elisabethendangsrimariani@gmail.com

RS. Santa Elisabet.

J1.. Kawi I, Semarang, 50231.

\section{INTRODUCTION}

Total knee replacement (TKR) has revolutionized the care of patients with end-stage knee joint disease. They offer almost miraculous pain relief and functional improvement for patients who are disabled by pain and deformity. ${ }^{1}$ The indications for TKR are pain and/or dysfunction caused by cartilage damage to the knee. The most common reason is osteoarthritis, but other causes include rheumatoid arthritis, post traumatic arthritis, and osteonecrosis. $^{2}$

The only orthopedic precaution following a TKR is the weight bearing restriction. Patients should ambulate independently with a walker or crutches, but this frequently exhibits a "stiff knee" gait, muscle weakness, low endurance, or poor of balance. These problems should be overcome step by step so patients can reach functional outcome nearing normal level for chronological age.

In recent years, there has been a widespread interest in aquatic therapy that rapidly becomes 
a popular rehabilitation technique for treatment of various patient population ${ }^{3}$, including the ones with post TKR. Properties of water, physical laws and proper exercise techniques can be used to solve common problems faced by post TKR patients. Although aquatic therapy facilities are available in rehabilitation centers, often it is not optimally used. This is due to (1) lack of understanding and skills in making use the essential properties of water and law of motion for therapeutic use, and (2) doubt about the superiority of aquatic therapy compared with land based therapy, as well as apprehension on risk of exercise in water environment for patients with post TKR.

This article is aimed at (1) describing proper exercise technique in water environment for post TKR patients and (2) discussing results of the researches on aquatic therapy as a part of rehabilitation program in order to enhance patient's recovery after TKR more than land based therapy.

\section{The Aquatic Therapy}

Aquatic therapy can be defined as the use of water and as an activity specifically designed by qualified personnel to aid in the restoration, extension, maintenance, and functional ability in person with acute, transient, or chronic disabilities, syndromes or diseases. ${ }^{(4)}$

A. Physical Laws as applied to The Aquatic Environment

1. Essential Properties of Water

Bouyancy. Archimedes' principle states that an immersed body at rest experiences an upward thrust that is equal to the weight of the same fluid volume it displaces. ${ }^{3,5,6}$ Buoyancy reduces weight bearing to the body's joints and is based on the depth of the water. ${ }^{3,6}$

Viscosity refers to the friction between molecules of a liquid or gas, causing the molecules to adhere to each other (cohesion) and, in water, to a submerged body (adhesion). ${ }^{6}$ Turbulent flow increases the water's resistance. ${ }^{3,5,6}$

Drag, the resistance to movement in the water, is a function of fluid characteristics (viscosity), frontal shape and size (bow force), and the relative velocity between the participant and the water (how water is moving and how the participant is moving in the water). ${ }^{3,6}$

Hydrostatic pressure is defined as the pressure exerted by molecules of fluid on an immersed body. According to Pascal's law, pressure is equally exerted on all surfaces of an immersed body at rest at a given depth. 5,6

Surface Tension. There is a slight but easily overcome cohesive force that runs in a parallel direction to the water surface. ${ }^{3,6}$

2. Newton's Law of Motions

Sir Isaac Newton's three laws of motion are key elements in altering intensity of aquatic exercise. ${ }^{6}$

The law of inertia states that an object will remain at rest or in motion with constant velocity (speed and direction) unless acted on by a net external (unbalanced) force 
(Ostdiek and Bord 1994). In water exercise, three things are affected by the law of inertia i.e movement of the limbs (limb inertia), movement of the entire body (total-body inertia), and movement of the water (water inertia). ${ }^{6}$

According to the law of acceleration, the reaction of a body is proportional to the force applied and is inversely proportional to its mass. Acceleration involves how fast an object will change its direction or speed when a force is applied, or how quickly its velocity changed. Objects with a larger mass require a greater external force to change speed at the same rate as a smaller object does. ${ }^{6}$

According to the law of action and reaction, for every action, there is an equal and opposite reaction. The properties of water make action and reaction noticeable with every movement. ${ }^{6}$

\section{Additional Training Principles}

Frontal Resistance. Since the force of gravity is offset by the water's buoyant force, the primary resistive force experienced in the pool is horizontal resistance..$^{5,6}$

Levers. The amount of force required for movement is based on the length of the lever arm. Shorter levers (bent arms and legs) require less force to move than longer levers (straight arms and legs). ${ }^{6}$

Speed of movement. The resistance of the water increases with the speed of movement $(3,4)$, which requires additional muscular effort and results in greater caloric expenditure (Pinto et al. 2011; Pöyhönen et al. 2000). ${ }^{6}$

4. Physiologic Responses to Immersion Effects of Hydrostatic Pressure. The hydrostatic pressure encountered results in changes in cardiovascular dynamics even before exercise is initiated. ${ }^{5,7}$ Immersion to the neck results in centralization of peripheral blood flow. Risch et al found that the heart rate (HR) remains unchanged or decreases, depending on the depth of immersion, the individual's comfort level in the water, water temperature, and type and intensity of exercise. Exercise while immersed to the neck will produce a HR of 8 to 11 beats per minute lower than similar land-based exercise. $^{5}$

B. Effects of Water Temperature. Water that is too warm or too cold can add a significant thermal load to the cardiovascular system. Thermoneutral temperature is suggested to be approximately $34^{\circ} \mathrm{C}$. ${ }^{(5)}$

C. Precaution and screening before joining Aquatic Therapy

Significant physiologic changes occur with immersion at various depths. These responses may produce either desirable effects (e.g., control of lower extremity edema) or undesirable ones (e.g., limitation of lung expansion). ${ }^{5} \mathrm{So}$, it is important to screen the patients before providing aquatic therapy. 
Table 1. Patient Screen for Aquatic Rehabilitation ${ }^{3,5}$
Basic safety
Ability to enter/exit the pool safely
Comfort in the water
Ability to put face in the water
Rhythmic breathing/bobbing
Ability to supine and prone float and recovery
Turning over
Precautions to aquatic environment
Cardiac history
Seizure disorder controlled with medications
Fear of the water
Any precautions to land exercise (i.e., diabetes)
Limited lung capacity
Contraindications to aquatic environment
Fevers, infections, rashes
Open wounds without Bioclusive dressing
Incontinence without protection
Unstable cardiac conditions
Uncontrolled high or low blood pressure
Uncontrolled seizure disorder

\section{Rehabilitation for Patiens with Post TKR}

Rehabilitation of knee replacement is critical to a successful outcome. It allows the patient to overcome mobility, strength, and motion defects that have developed over time. ${ }^{2}$

\section{Rehabilitation goals}

On the first day, the patient is supervised in performing deep breathing, isometric lower extremity, active ankle range-of-motion exercises, and in-bed mobility wearing a knee immobilizer that is used until the third or fourth postoperative day. ${ }^{1}$ In addition, 4-6 hour CPM with a limit of 40 degrees for the first 4 days post operatively and progression of 10 degrees per day there after can be used. ${ }^{8}$

Common problems faced by post TKR patients There are swelling of the knee and peripheral edema, decreased ROM, decreased strength, decreased balance/ proprioception/ coordination, weight-bearing restriction, cardiovascular deconditioning or low endurance, gait deviation, difficulty or pain with land interventions, social, emotional problem that can lead to ADLs dependency.

Aquatic Therapy as a Part of Rehabilitation Program Following TKR

Interventions following joint arthroplasty commonly consist of land-based exercise as a primary mode of rehabilitation and is often combined with modalities such as electrical stimulation, heat or cryotherapy. However, landbased exercise and the use of modalities may not always be an optimal approach. Properties of water and proper exercise techniques are offered to solve common problems faced by post TKR patients. 
Tabel 2. Postoperative Rehabilitation Goals for Total Knee Replacement ${ }^{(2)}$

\begin{tabular}{|c|c|c|}
\hline \multicolumn{2}{|c|}{ Post Operative Phase } & Goals \\
\hline Phase I & $\begin{array}{l}\text { Acute Care } \\
\text { First } 3 \text { days - } \\
2 \text { weeks }\end{array}$ & $\begin{array}{l}\text { - Control post operative swelling } \\
\text { - Monitor pain levels } \\
\text { - } \text { Active assistive/active ROM: flexion }>80^{\circ} \text {, extension } 0^{\circ} \\
\text { - Unassisted transfers, ambulation, and stair negotiation (nonreciprocal) with } \\
\text { - } \text { Inpropriate assistive device } \\
\text { - Independent or modified independent with ADLs with assistive devices } \\
\text { Indent modified independent with home exercise program }\end{array}$ \\
\hline Phase II & $\begin{array}{l}\text { Subacute Care } \\
2-8 \text { weeks }\end{array}$ & $\begin{array}{l}\text { - Ongoing edema management and monitoring of pain levels } \\
\text { - Active assistive / active ROM : flexion }>1050 \text {, extension } 00 \\
\text { - Progress weight bearing status, if necessary } \\
\text { - } \text { Begin normalizing gait mechanics with or without assistive devices } \\
\text { - device to ascend and descend 4-inch step with handrail assist and assisted } \\
\text { - Modified independence or independence with ADLs } \\
\text { - Independent with home exercise program } \\
\text { - Initiate functional outcome measures for baseline levels }\end{array}$ \\
\hline Phase III & $\begin{array}{l}\text { Subacute Care } \\
9-16 \text { weeks }\end{array}$ & $\begin{array}{l}\text { - Ongoing edema management and monitoring of pain levels } \\
\text { - AROM : flexion }>1150 \text {, extension } 00 \\
\text { - Transfers and performs upright activity with equal limb symmetry and } \\
\text { equal weight bearing independently or with least restrictive assistive device } \\
\text { - Independence with ADLs } \\
\text { - Maximize lower extremity strength, control, and flexibility to meet the } \\
\text { demands of high level ADLs } \\
\text { - Reciprocal stairs negotiation : able to ascend and descend } 6 \text { to } 8 \text { inch step } \\
\text { with handrail assist and assistive device, if necessary }\end{array}$ \\
\hline
\end{tabular}

D. Solving common problems of TKR patients by using properties of water and proper exercise technique

1. Swelling and decreased ROM of the knee and peripheral edema

Based on Pascal's law, hydrostatic pressure increases with depth and fluid density of water, so exercise in pool is a good option to control edema. The hydrostatic pressure also produces centralization of peripheral blood flow. ${ }^{3,4,5}$ Edema reduction could benefit the patient by assisting in pain reduction and allowing ROM to increase. ${ }^{3}$
A study by Harmer et al compared outcomes between land-based and water-based exercise programs delivered in the early sub acute phase up to 6 months after total knee replacement. Significant improvements were observed across time in all outcomes (distance on the 6-Minute Walk test, stair climbing power (SCP), the WOMAC Osteoarthritis Index, visual analog scale for joint pain, passive knee range of motion, and knee edema) at 8 weeks, with further improvements evident in all variables (except WOMAC pain) at 26 weeks. Minor between-group differences were evident 
for 4 outcomes (SCP, WOMAC stiffness, WOMAC function and edema) but these appear clinically insignificant. ${ }^{9,10}$

Two or three times / week aquatic therapy can be combined with land-based therapy. Shonewill et al recommend a combination of aquatic and land-based therapy to improve ROM and strength as well as for decreasing edema and pain. ${ }^{3}$

2. Decreased strength

By using Archimedes' principles, strengthening exercises begin in the buoyancy- assisted to buoyancy-resisted exercises. Four main variables that can be manipulated to alter resistance or assistance are : position or direction of movement in the water, water depth, lever arm length, and flotation or weighted equipment use ${ }^{5}$. Because water is more viscous than air, it provides more resistance to motion than air. Streamlined flow is continuous, steady movement of fluid. When an object moves, the bow force causes an increase in the water pressure at the front of the object and a decrease in the water pressure at the rear of the object.

This pressure change causes a movement of water from the high-pressure area at the front to the low-pressure area behind the object. As water enters the low-pressure area, it swirls in to the low-pressure zone and forms eddies, or small whirlpool turbulences. Turbulent flow increases the water's resistance ${ }^{3,5,6}$ Another property of water, drag, creates different loading to the muscles during water exercise compared to land exercise. On land, muscle load decreases when we achieve a constant speed. In the water, there is a constant muscle load provided by the water, that is experienced with every movement and in every direction. ${ }^{6}$

The results of Valtonen's randomized controlled trial showed that 12 weeks of progressive aquatic training reduced mobility limitation by increasing walking speed and decreasing stair ascending time in persons with knee replacement. Knee extensor and flexor power and thigh muscle CSA increased with training, especially in the operated $\operatorname{leg}^{11}$. But, after the 12-month follow-up, the 12week aquatic training-induced benefits in knee extensor and flexor power were maintained, whereas the mobility benefits had disappeared. ${ }^{12}$

These studies suggest that aquatic resistance training in water is a feasible mode of rehabilitation that has ranging positive effects on patients after knee replacement surgery, and should be continued at least on some level to maintain the training- induced benefits in mobility.

3. Decreased balance/ proprioception/ coordination

The critical time for proprioceptive loss in the early postoperative period is described as 6-weeks. It has been suggested that this 6-week time may be a transition point between proprioceptive loss and early adaptations to new, learned motor patterns. ${ }^{13}$ Turbulence functions as a destabilizer and as a tactile sensory stimulus.

The stimulation from the turbulence generated during movement provides feedback and perturbation challenge that aids 
in the return of proprioception and balance. By placing a sinkable bench or chair in the shallow water, step-ups can be initiated under partial weight bearing conditions long before the patient is capable of performing the same exercise when full weight bearing on land is applied.

Thus, the advantages of diminished weight bearing exercises are coupled with the proprioceptive benefits of closed kinetic chain exercise, making aquatic therapy an excellent functional rehabilitation activity ${ }^{3}$

A study performed by Suomi and Koceja demonstrated that the women with arthritis who followed an aquatic exercise program based on AFAP protocol for 6 weeks significantly reduced their total sway area and their sway in the medial-lateral direction under the full vision condition ; they also reduced their total sway area and their sagittal and medial-lateral sway in the no-vision condition; which placed them in lower risk for falls. ${ }^{14}$

\section{Weight-bearing restriction}

By applying buoyancy principles, the aquatic environment can provide a gradual transition from non weight bearing to full weight bearing land exercises. It is systematically accomplished by moving the patient from neck-deep water to shallower water. ${ }^{3}$

5. Cardiovascular deconditioning or low endurance

Studies show that exercise in water requires higher energy expenditure than the one performed on land. The patient has to perform some activities as well as to maintain a level of buoyancy while overcoming the resistive forces of the water. For example, the energy cost for water running is 4 times greater than the energy cost for running the same distance on land. ${ }^{3}$

Exercise technique should be matched to the needs of the individual patient. For example, a healthy young adult can be trained with progressively higher intensity; whereas for others with lower physical wellness training can be started with lower intensity.

Because of the hydrostatic effects on heart efficiency, an environment-specific exercise prescription is necessary. Some researches suggest the use of perceived exertion as an acceptable method to control exercise intensity. Other researches suggest the use of target heart rate values as with land exercise, but compensate for the hydrostatic changes by setting the target range about $10 \%$ lower than the one for land-basedexercise ${ }^{3}$ 
Table 3. Increasing and Decreasing Intensity in Water Exercise ${ }^{(6)}$

\begin{tabular}{llll}
\hline \multicolumn{1}{c}{ Law of principle } & \multicolumn{1}{c}{ To increase intensity } & \multicolumn{1}{c}{ To decrease intensity } \\
\hline $\begin{array}{l}\text { Law of inertia } \\
\begin{array}{l}\text { Total-body inertia, water } \\
\text { inertia, and limb inertia }\end{array}\end{array}$ & $\begin{array}{l}\text { Combine movements to start, stop, and } \\
\text { change direction. Use fewer repetitions in } \\
\text { a combination. Add traveling movements. }\end{array}$ & $\begin{array}{l}\text { Repeat the same move for several } \\
\text { repetitions. Remain in place (no travel) }\end{array}$ \\
$\begin{array}{l}\text { Force and mass } \\
\text { Push harder against the water's } \\
\text { resistance or against the pool bottom to } \\
\text { jump higher or take larger steps. }\end{array}$ & $\begin{array}{l}\text { Skim the arms through the water, reduce } \\
\text { range of motion, take smaller steps, or } \\
\text { apply less resistance to the pool bottom } \\
\text { or against the water. }\end{array}$ \\
$\begin{array}{l}\text { Law of action and } \\
\text { reaction Opposing forces }\end{array}$ & $\begin{array}{l}\text { Use impeding arms, legs, or } \\
\text { combinations. }\end{array}$ & $\begin{array}{l}\text { Use assisting arms, legs, or } \\
\text { combinations }\end{array}$ \\
$\begin{array}{l}\text { Frontal resistance-body } \\
\text { and limbs }\end{array}$ & $\begin{array}{l}\text { Increase the size of the frontal surface } \\
\text { area (body or limb) presented in the line } \\
\text { of travel }\end{array}$ & $\begin{array}{l}\text { Decrease the size of the frontal surface } \\
\text { area (body or limb) presented in the line } \\
\text { of travel. }\end{array}$ \\
$\begin{array}{l}\text { Frontal resistance hand } \\
\text { positions }\end{array}$ & $\begin{array}{l}\text { Cup the hand with the fingers slightly } \\
\text { apart }\end{array}$ & $\begin{array}{l}\text { Slice the hand through the water or } \\
\text { make a fist. }\end{array}$ \\
$\begin{array}{l}\text { Levers } \\
\text { Long and short levers }\end{array}$ & $\begin{array}{l}\text { Use long levers with extended arms and } \\
\text { legs.* }\end{array}$ & $\begin{array}{l}\text { Use shorter levers with flexed arms and } \\
\text { legs. }\end{array}$ \\
\hline Speed of movement & Increasing speed ** & \begin{tabular}{l} 
Decreasing speed \\
\hline
\end{tabular}
\end{tabular}

* Although increasing the lever arm increases intensity, there is no benefit to working with locked or hyperextended limbs. Maintaining a slight bend in the limb (soft joints) actually provides a slight training advantage by creating eddies, which in turn increase turbulence. Maintaining soft joints also reduces strain to the soft tissue in the joint and better ensures that the intended muscle will provide the effort. ${ }^{(6)}$

** When speed is increased, range of motion and body position can be compromised. When we cue patients to go faster, they will often choose to reduce range of motion to achieve a faster speed, rather than adding force and maintaining range of motion. Although increasing speed does increase intensity, it is only one of the many tools available in aquatic exercise design. The most effective and functional way to train a muscle is through its full range of motion. ${ }^{(6)}$

Bade et al examined the safety and efficacy of a high-intensity progressive rehabilitation protocol beginning 4 days after TKR compared to a low-intensity rehabilitation protocol on 162 participants. Key components of the high-intensity intervention were the use of progressive resistance exercises and a rapid progression to weight-bearing exercises and activities.
In conclusion, both high-intensity and lowintensity interventions were effective in improving strength and function after TKR. High-intensity progressive rehabilitation is safe for individuals after TKR. However, its effectiveness may be limited by arthrogenic muscular inhibition in early postoperative period. ${ }^{1}$ 


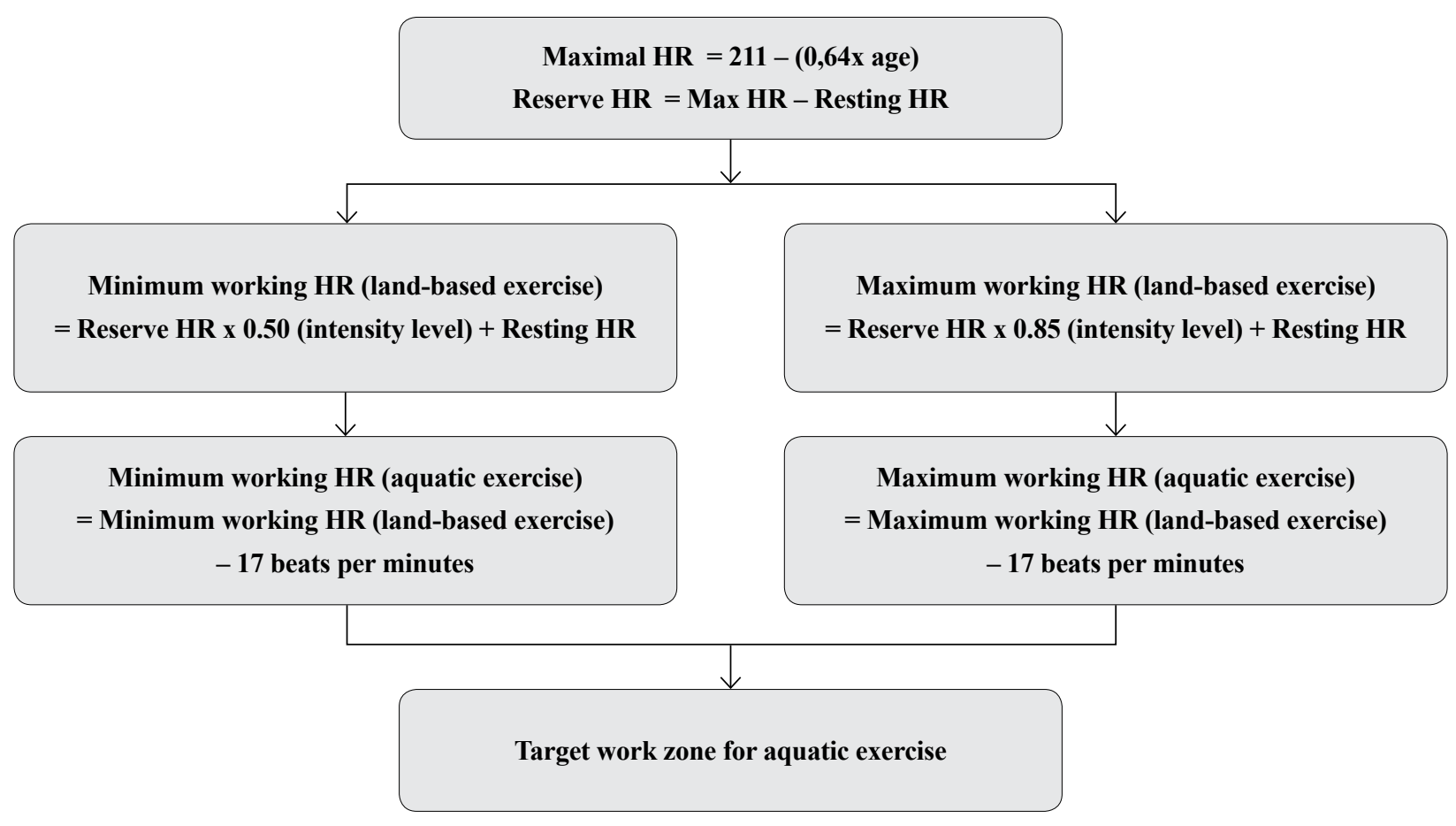

Fig. 1. Karvonen Formula for water exercise ${ }^{3}$

6. Gait deviation

Compared with air, water has higher viscosity causing slower movement. This will ease gait pattern assessment and correction. ${ }^{3}$

7. Difficulty or pain with land interventions Patients get increased support, decreased weight-bearing, assistance, and a more relaxed environment as a result of buoyancy. ${ }^{3}$

8. Social and emotional problem

Although water activities do not always solve life's problems, swimming enriches life and provides opportunities for increased morale and body image (Benedict \& Freeman, 1993), improved mood (Berger \& Owen, 1992), and decreased depression (Stein \& Motta, 1992). ${ }^{16}$ The positive effects of hydrotherapy on mood can be a great help in the management of subclinical surgerycorrelated depression. ${ }^{17}$
9. Functional Disability

Western Ontario and McMaster Universities Osteoarthritis Index (WOMAC) is an easilyadministered instrument that is widely used to evaluate outcomes of osteoarthritis interventions, both conservative and surgical. In Giaquinto's study, participant were randomly assigned to either a conventional gym treatment $(\mathrm{N}=30)$ or hydrotherapy $(\mathrm{N}=28)$. A prospective design was performed. Participants were interviewed at admission, at discharge and six months later. Both groups improved. The WOMAC subscales, namely pain, stiffness and function, were all positively affected. Statistical analysis indicates that scores on all subscales were significantly lower for the hydrotherapy group. The benefits gained by the time of discharge were still found after six months. Hydrotherapy is recommended after total knee arthropalsty in a geriatric population. ${ }^{18}$ 
Areview conducted by Papalia et al showed that aquatic therapy produced a beneficial effect on the clinical outcome after TKR. The WOMAC index improved in four out of six studies, similarly to SF-36 score, Lequesne Hip/Knee score, and patient satisfaction score. ${ }^{19}$

A systematic review by Gifford et al upon 6 articles resulted that (1) When comparing landbased therapy to aquatic therapy, there was a greater improvement in stair climbing power, WOMAC function score, edema and knee flexion range of motion in patients who received aquatic therapy (2) Following total knee arthroplasty, patients receiving early aquatic therapy showed significant improvements in overall function compared to those who started aquatic therapy late, whereas no differences were found in patients who underwent total hip arthroplasty, (3) Aquatic therapy programs have also been shown to increase hip abductor strength, quadriceps strength, knee flexion power, knee flexion range of motion, increased habitual walking speed, decreased stair ascending time and thigh muscle cross sectional area,(4) At 12-month follow-up, a 32\% effect in knee extensor power and 50\% effect in knee flexor power of the operated knee remained in the aquatic therapy group. However, the training effects in mobility and muscle CSA had disappeared. In conclusion, aquatic physical therapy can be an effective treatment following total knee or hip arthroplasty.

Goehring et al reviewed 6 articles about the effectiveness of aquatic therapy following total hip or total knee arthroplasty. Four articles found significant differences favoring aquatic therapy, one article found no differences between aquatic and land therapy, and one article found no differences between specific aquatic, non specific aquatic and land therapy. As a conclusion, aquatic therapy is a viable intervention option for improving function, pain and quality of life in individuals following TKA or THA. ${ }^{4}$

On the other hand, Gibson et al had different findings. Three small trials of moderate quality were included in the qualitative analysis. This systematic review and meta-analysis suggests that there is currently not enough evidence to support or refute the hypothesis that aquatic therapy in combination with land-based therapy provides a clinically meaningful advantage over land-based therapy alone for rehabilitation after knee replacement. ${ }^{21}$

\section{Disadvantages and Undesirable Effects of Aquatic Therapy}

Physiatrist are sometimes in doubt in suggesting aquatic therapy for post TKR patients, i.e. whether it is safe and worthy. The doubt also covers the followings: will there be complication on the surgery wound, how early aquatic therapy should be safely initiated, and what risk and complication might happened during and after water-based exercise.

Rahmann et al evaluated the effect of inpatient aquatic physiotherapy in addition to usual ward physiotherapy. Participants were randomly assigned to receive supplementary inpatient physiotherapy, beginning on day 4: aquatic physiotherapy, non specific water exercise, or additional ward physiotherapy. The research indicated that a specific inpatient aquatic physiotherapy program had a positive effect on early recovery of hip strength after joint replacement surgery. No adverse events occurred in either of the groups who came to the 
pool early after THR or TKR surgery, indicating that aquatic physiotherapy is a safe and effective alternative to additional ward physiotherapy. ${ }^{22}$

Next, Liebs et al conducted a multicenter randomized controlled trial, comparing early versus late aquatic therapy after total hip or knee arthroplasty. They found that after TKR all WOMAC subscales in the early aquatic therapy group (6 days after TKR) were more superior compared with the late group (14 days after TKR). ${ }^{23}$. Meanwhile, Department of PMR Northwestern University Medical School allows patients to begin pool therapy as early as postoperative day 5 if their incision is closed, not draining, and is approximated with staples (not sutures). ${ }^{1}$

After orthopedic surgery, early aquatic physical therapy improves function, but it does not increase the risk of wound-related adverse events, as described in meta-analysis comclussion by Villalta et al. ${ }^{24}$

Several studies reposted complications, including infections, burns, folliculitis and hypersensitivity pneumonitis which related to hydrotherapy. ${ }^{25}$

Other problems connected with aquatic therapy are cost and organization. Aquatic exercises may be more expensive than land-based exercise therapy and is more difficult to provide hygiene. However, it might have some advantages, such as relieving pain, decreasing stiffness, or relaxing muscle. Therefore, aquatic exercises might be preferred in the initial session if there is stiffness or a lot of pain in extremity 26 It is important to establish cost effectiveness of water-based therapy in comparison to land- based therapy, as well as to the combination of both therapies.

\section{DISCUSSION}

The importance of early mobilization after orthopedic surgery has been well documented. Early mobilization, however, can be limited by pain and reduced muscle coordination, strength, and ability to bear weight in the early postoperative period.

By using properties of water, physical laws and proper exercise techniques, aquatic therapy is offered to solve common problems faced by post TKR patients. Hydrotherapy can be used for muscle strengthening, flexibility, cardiovascular fitness, and improved psychological effects. The physical properties of water in a hydrotherapy pool make it a medium that provides the support and comfort in which to commence exercising in early rehabilitation post surgery: buoyancy decreases apparent body weight and lower limb internal joint forces, allowing postoperative subjects to practice walking unaided in water early in their rehabilitation. Drag forces provide resistance to movement, which allows the progression of exercises throughout rehabilitation. When immersed, the body has fluid pressure (which increases with depth) exerted on all surfaces. The resulting hydrostatic pressure gradients produced during immersion cause a shift in fluid from the lower limbs to the cardiothoracic compartment, which can result in a reduction of edema in the legs.

Although there is inconsistency in research results comparing the effects of water-based exercise and land-based exercise, of all studies aquatic therapy is not said to be worst than land-based therapy. 
Aquatic therapy is also considered safe though started on day-4 post surgery.

As a tool, aquatic therapy has desirable and undesirable effects. The followings should be prepared in applying aquatic therapy : preparing the patients (assessing problems faced by the patients, conducting screening to determine patient availability following aquatic therapy), preparing human resources (achieving mastery and skills in using essential properties of water and law of motion in for therapeutic goals based on individual condition of the patient), preparing the facilities (hygiene, water temperature, affordable cost (for the continuity of the program), and determining aquatic therapy protocols for post THR patients.

So far there has been no agreement in aquatic therapy protocols for post TKR patients. Further study should be done to find out the optimum number of weekly exercise, the most appropriate type of exercise and find out whether waterbased exercise is better combined with land based exercise.

\section{CONCLUSION}

Aquatic therapy can provide an alternative intervention for patients who may have difficulty with or cannot accomplish land-based physical therapy after TKR. Moreover, it has a positive influence on social behavior and mood. This may be more advantageous in the early postoperative phase when patients are limited by pain, and fortunately these therapy programs can begin anytime from 4 days after TKR. In the contrary, the obstacle may occur on the availability of budget for facility maintenance and hygiene, as well as the availability of competent human resources. To obtain the optimum aquatic therapy benefits, patients assessment, human resources and facility preparation, and therapeutic exercise program based on patient condition are neded.

\section{ACKNOWLEDGEMENTS}

We would like to thank dr Rudy Handoyo, SpKFR (K), dr Tanti Ajoe Kesoema SpKFR (K), PMR Department of Dr Kariadi General Hospital Faculty of Medicine Diponegoro University and PMR Department of St. Elisabeth Hospital Semarang for their support.

\section{REFERENCES}

1. Brander VA, Stulberg SD, Chang RW. Rehabilitation following hip and knee arthroplasty. Physical Medicine and Rehabilitation Clinics of North America 1994; 5(4): 815-36.

2. Haas S, Ricciardi BF, Reyes DV. Total Knee Arthropasity. In: Green A, Hayda R, Hecht AC editors. Postoperative Orthopaedic Rehabilitation. New York: Academy of Orthopaedic Surgeons; 2018. p. 401-16

3. Hoogenboom BJ, Lomax NE. Aquatic therapy in rehabilitation. In: Prentice WE. editor. Rehabilitation techniques for sport medicine and athletic training. $7^{\text {th }}$ ed. Thorofare, NJ: SLACK Incorporated; 2020. p.379-404.

4. Goehring $\mathrm{M}$, Bergmooser $\mathrm{AB}$, Decker KJ, Mason NR, Kinne B. The effectiveness of aquatic therapy following total hip or total knee arthroplasty: a systematic review. The 
Journal of Aquatic Physical Therapy 2015; 23(2): 2-12.

5. Brody LT. Aquatic physical therapy. In: Brody LT, Hall CM editors. Therapeutic exercise moving toward function. $3^{\text {rd }}$ ed. Baltimore, MD: Lippincott Williams \& Wilkins; 2011. p.355-72.

6. Aquatic Exercise Association. Aquatic fitness professional manual. Champaign, IL: Human Kinetics; 2018.

7. Becker BE. Aquatic therapy: scientific foundations and clinical rehabilitation applications. AAPMR. 2009; 1: 859-72.

8. Manske RC, Nigrini CM, Brotzman SB. The arthritic lower extremity. In: Brotzman SB, Manske RC editors. Clinical orthopaedic rehabilitation - an evidence based approach. $3^{\text {rd }}$ ed. Philadelphia: Elsevier; 2011. p.371-92.

9. Harmer AR, Naylor JM, Crosbie J, Russell T. Land-based versus water based rehabilitation following total knee replacement: a randomized, single blind trial. Arthritis and Rheumatism. 2009; 61(2): 184-91.

10. Artz N, Elvers KT, Lowe CM, Sackley C, Jepson P, Beswick AD.Effectiveness of physiotherapy exercise following total knee replacement: systematic review and metaanalysis. BMC Muskoloskeletal Disorders. 2015; 16: 15-20

11. Valtonen A, Poyhonen T, Sipila S, Heinonen A. Effects of aquatic resistance training on mobility limitation and lower-limb impairments after knee replacement. Arch Phys Med Rehabil. 2010; 91: 833-9.

12. Valtonen A, Poyhonen T, Sipila S, Heinonen A. Maintenance of aquatic trininginduced benefits on mobility and lower- extremity muscles among persons with knee replacement. Arch Phys Med Rehabil. 2011; 92: 1944-50.

13. Guney-Deniz H, Callaghan M. Proprioception after the arthroplasty. In: Kaya D editor. Proprioception in Orthopaedics, Sports Medicine and Rehabilitation. New York : Springer International Publishing; 2018. p. $149-58$.

14. Suomi R, Koceja DM. Postural sway characteristics in women with lower extremity arthritis before and after an aquatic exercise intervention. Arch Phys Med Rehabil. 2000; 81(1): 780-85.

15. Bade MJ, Struessel T, Dayton M, Foran J, Kim RH, Miner T e al. Early high intensity versus low=intensity rehabilitation after total knee arthroplasty: a randomized controlled trial. Arthritis care and Research. 2017; 69(9): $1360-8$.

16. Lepore M, Gayle GW, Stevens S editors. Introduction to adapted aquatics. Champaign, IL: Human Kinetics; 2007.

17. Bistolfi A, Federico AM, Carnino I, Gaido C, Rold ID, Magistroni E, et al. Rehabilitation and physical therapy before and after total knee arthroplasty: a literature review and unanswered questions. Int $\mathrm{J}$ Phys Med Rehabil. 2016; 4(5) : 356-62

18. Giaquinto S, Ciotola E, Dall'Armi V, Magutti F. Hydrotherapy after total knee arthroplasty. A follow up study. Arch Gerontol geriatr. 2010; 51(1): 59-63.

19. Papalia R, Campi S, Vorini F, Zampogna B, Vasta S, Papalia G et al. The role of physical activity and rehabilitation following hip and knee arthroplasty in elderly. J Clin Med 2020; 9:1401. 
20. Gifford G, Miller J, Speca G, Woodcock H, Leininger $\mathrm{P}$. The effects of aquatic therapy on patients who have undergone total hip or knee arthroplasty. Pennsylvania: University of Scranton

21. Gibson AJ, Shields N. Effects of aquatic therapy and land-based therapy versus landbased therapy alone on range of motion, edema, and function after hip or knee replacement: a systematic review and meta-analysis. Physiother Can. 2015; 67(2): 133-141.

22. Rahmann AE, Brauer SG, Nitz JC. A specific inpatient aquatic physiotherapy program improves strength after total hip or knee replacement surgery: a randomized controlled trial. Arch Phys Med Rehabil. 2009; 90: 74555 .

23. Liebs TR, Herzberg W, Ruther W, Haasters J, Russlies M, Hassenpflug J et al. Multicenter randomized controlled trial comparing early versus late aquatic therapy after total hip or knee arthroplasty. Arch Phys Med Rehabil. 2012; 93: 192-9.

24. Villalta EM, Peiris CL. Early aquatic Physical therapy improves function and does not increase risk of wound-related adverse events for adult after orthopedic surgery: a systematic review and meta-analysis. Arch Phys Med Rehabil. 2013; 94: 138-48.

25. Martin CW, Noertjojo K. Hydrotherapy, review on the effectiveness of its application in physiotherapy and occupational therapy. Melbourne: Work Safe; 2004.

26. Sayaca, C, Kocabey Y, Cicek EI. Osteoarthritis and proprioception. In: Kaya D (eds). Proprioception in Orthopaedics, Sports Medicine and Rehabilitation. New York: Work Safe. 2018. p. 175-87 